\title{
INVESTIGATING THE DROP-OUT RATE FROM A BIM FOR INFRASTRUCTURE COURSE
}

\author{
Raido Puust, Emlyn Witt, Irene Lill and Roode Liias \\ Tallinn University of Technology, Tallinn, Estonia
}

\begin{abstract}
This research examines how personal time management relates to successful course completion or dropping-out from a high intensity building information modelling (BIM) e-learning course. The course has been developed during 2017-2018 and uses peer instruction to engage students with the intention of improving their performance. Students' activity data were captured and analysed according to their study groups and suggested study module completion dates. The findings suggest that distance learners had a higher drop-out rate than study program students and that lagging the suggested study module completion dates did not necessarily lead to dropping-out. This paper represents a first step in ongoing research to understand the effectiveness of peer instruction in high intensity BIM courses.
\end{abstract}

\section{Introduction}

Building information modelling (BIM) has been noted as a possible solution to improve the construction industry's poor productivity (McKinsey\&Company, 2017). BIM supports the full lifecycle of built assets and has been in use from the early 2000s but, more than a decade later, we still need to address the fact that the full potential of BIM has not yet been realised. Existing research exploring the key barriers to successful BIM implementation (for example, Won et al., 2013; Halttula et al., 2015; Olawumi et al., 2018) has found that the steep learning curve and lack of understanding of BIM processes and workflows are significant challenges. To overcome these, we should focus on how BIM is taught (Sacks et al., 2018).

Numerous research studies have investigated BIM education program development (Sacks and Pikas, 2013; Forsythe et al., 2013). Built environment-related educational requirements have changed in order to meet emerging industry needs in terms of BIM-related topics, including new job roles (Abdirad and Dossick, 2016; Gustafsson et al., 2015; Lindblad and Vass, 2015; Succar et al., 2013; Uhm et al., 2017) and to enhance construction professionals' career paths (Wu and Issa, 2013; Uddin and Khanzode, 2014). Key considerations in developing university course programs for BIM include: (a) the availability of the software which helps to practice key workflows (Russell et al., 2014; Tuchkevich et al., 2015); (b) the need from the industry to push BIM topics into firstor second-year study programs (Vinšová et al., 2015) by eliminating the prerequisite of computer aided design (CAD) topics as this will be a result from the BIM model and not the opposite (Sacks and Barak, 2010); (c) helping faculty members to redesign their courses according to industry needs due to the availability of BIM workflows (Russell et al., 2014; Peterson et al., 2011; da Silva Vieira and Neto, 2016) and, as such, removing a significant barrier to integrating BIM into current university programs in some countries (Abbas et al., 2016); and (d) focusing on workflows which involve several tools to be learned rather than narrowing the knowledge to a single product's features only.

Various broad educational theories (behaviourist, cognitivist, constructivist, etc.) have shaped the design of e-learning courses and more specific, theoretical models of e-learning have been developed (Ally, 2004). For example, Anderson (2011) proposed a robust online learning model where interactions of learning are divided between community/collaborative (communication) and self-paced instructional models. From a communication perspective, learning may be divided into: synchronous and asynchronous. Asynchronous learning is primarily self-learning with little support from the teacher. These include typical elearning courses and commercially available examples of BIM e-learning which often focus on a single, specific topic/software (e.g. LinkedIn Learning, Coursera, Udemy) while some enhance this by setting a personal learning path first and then focus on specific topic/software learning content (e.g. Pluralsight). Common to these are the assumption that learners can self-learn without direct and continuous support. Since there are various types of learner, this type of learning may easily lead to learners dropping out from the learning path or gaining an incomplete (even misleading) understanding of key topics. More importantly, since such learning solutions typically focus on a specific topic or software, it also means that the BIM process through the facility's full lifecycle is not correctly understood and the development of essential collaboration skills suffers. (This point may be equally valid for face-to-face training where only one particular topic/software is dealt with.)

Synchronous learning, on the other hand, assumes that each student actively participates in the learning process and this implies that discussion is a key part for all. Active learning can be simulated in a classroom or an e-learning environment. It is mainly limited time that restricts the "all-involved" learning experience within the classroom, so e-learning tools can make 
it easier to set the rules of active learning. Examples of elearning that incorporate active learning components include massive open online courses (MOOCs) that run within a certain timeframe and ensure that all students are involved in the learning process (e.g. Adobe Education Exchange, Udacity).

Several research papers analyzed active learning vs classical lectures in terms of student performance in science, engineering and mathematics (Freeman et al., 2014). Active learning embraces various teaching methodologies. For example, peer instruction (PI) as an active teaching method was popularized by Harvard Professor Eric Mazur in the early 1990s (Mazur, 1997). The main idea of PI is to help students learn more from pre-class reading and to increase students' engagement in discussion sessions (Crouch and Mazur, 2001; Alcalde and Nagel, 2018). Teacher availability and readiness to answer questions from the whole group is widely valued by students as it helps them to develop during the course and this reduces the failure rate (Zingaro and Porter, 2014). PI as a teaching method is similar to other methods that share the same logic as flipped or inverted classroom (Bates and Galloway, 2012; Hsieh et al., 2015; Wang et al., 2018) or active learning (Lassen et al., 2018). Classical PI assumes that people in a PI session are equally involved (each and everybody is participating in discussions) but this is not always the case because it is not made compulsory. Therefore, special versions of PI have been developed in which each participant should ask a question before entering the discussion group as in the 'stepladder' technique (Rogelberg et al., 1992; Michinov et al., 2015).

The current research relates to BIM courses developed over the period of 2017-2018. These courses are BIM workflow-based active learning courses that incorporate PI throughout the semester. The wider research is intended to investigate how PI can enhance the BIM learning experience and reduce course drop-out rates thus promoting a better and more complete understanding of BIM and, ultimately, to help drive BIM adoption and quality in industry. This research paper presents a preliminary investigation of how students' personal time management throughout BIM course participation relates to the drop-out rate and successful course completion. In the following section, the design and development of the BIM for infrastructure course is described. The methods of data collection and analysis are then explained, and the results obtained are presented before conclusions are drawn.

\section{Course design}

Three separate BIM courses were developed during 20172018 in Tallinn University of Technology (TalTech). One with a focus on buildings, one for infrastructure and one for advanced BIM studies that combines both buildings and infrastructure topics.

In this research, the analysis is carried out for the second of these, "BIM for Infrastructure". BIM can be used as a general term for any building-related design discipline, if infrastructure is in focus, several other terms are used, like civil integrated management or civil information management (CIM) or from the bridges context, bridge information modeling (BrIM). In general, bridges and buildings belong to the same, structures class, and have similar features, the key difference is in the construction process, operation and classification of parts (Costin et al., 2018). Vertical construction (building) differs from horizontal construction (e.g. bridge, road, tunnel, etc.), and each has different components, operations and techniques from planning through construction, operation and maintenance. BIM use in building-related projects is currently more advanced with BIM for infrastructure behind it in terms of development. The success of BIM deployment needs effort from both industry and academia. Although there are similarities, BIM implementation from the building or infrastructure perspective requires a different focus in terms of training, study programs, standards and guidelines. Recently, Estonia has adopted Finnish BIM for infrastructure guidelines to speed up the adoption and common understanding of BIM workflows for transportation infrastructure development.

In addition to TalTech, this course is given also at TTK University of Applied Sciences (TTK UAS). Due to new study programs, the course will be taught in TalTech from the 2020 spring semester, but in TTK UAS it has already been given for three semesters (2017 spring, 2018 spring and 2018 autumn). Therefore, this research focuses on the data that has been gathered from TTK UAS. It should be noted that in 2017-2018 the course was taken during students' fourth semester (second year), but from 2018 autumn a slight change was made to the study program and the course was rescheduled to the third semester (second year).

Table 1 shows how the "BIM for infrastructure" course evolved from 2017 spring to an updated version from 2018 autumn. The typical BIM course, if not based on one software package only, is usually a high educational density course, which means that it may include around 20 different tools to be learned (Fonseca et al., 2017). The course has been designed as an active learning course in a university wide Moodle e-learning system. It is divided into several modules (Table 2), each one of which has its own learning outcomes and assessments.

The core idea of the course is to teach the BIM process from the modelling perspective and to include collaborative exercises. The course begins with introductory lectures (usually during the first 2 weeks, $3 \mathrm{x}$ $45 \mathrm{~min}$ at one time). 
Table 1: Educational density of the "BIM for infrastructure" course in different study programs

\begin{tabular}{|l|l|c|}
\hline Course name & Topics covered & $\begin{array}{l}\text { Software packages and/or services } \\
\text { included }\end{array}$ \\
\hline $\begin{array}{l}\text { Building Information } \\
\text { up to spring 2018) }\end{array}$ & $\begin{array}{l}\text { Introduction to BIM for } \\
\text { infrastructure, BIM use in BIM for } \\
\text { preliminary design to detailed } \\
\text { design, intelligent planning, virtual } \\
\text { design and construction, BIM for } \\
\text { visualization (including virtual } \\
\text { reality), model-based collaboration } \\
\text { workflows. }\end{array}$ & $\begin{array}{r}\text { major tools used (incl. Autodesk } \\
\text { InfraWorks, AutoCAD Civil 3D, } \\
\text { Design, Autodesk Navisworks } \\
\text { Manage, Autodesk 3ds Max, } \\
\text { Autodesk 3ds Max Interactive, } \\
\text { Autodesk Viewer, MAGNET } \\
\text { Explorer }\end{array}$ \\
\hline $\begin{array}{l}\text { Building Information } \\
\text { Modeling (3 ECTS credits, } \\
\text { from 2018 autumn) }\end{array}$ & $\begin{array}{l}\text { In addition to previous list: BIM in } \\
\text { road rehabilitation workflows. }\end{array}$ & $\begin{array}{c}\text { 10 major tools used (in addition to } \\
\text { previous list: Autodesk ReCap) }\end{array}$ \\
\hline
\end{tabular}

At the same time, the students start to carry out individual tasks and assessments (Table 2). Peer instruction is simulated in an e-learning environment, where each student must formulate at least one question at the end of the course module and answer or discuss another student's questions. This is a key differentiator from the classical lecture where only the most active students formulate questions/answers. The e-learning system ensures that each student has formulated one question and answered somebody else's question.

Table 2: Course learning modules (LM), assessments (version 2018 autumn)

\begin{tabular}{|c|c|}
\hline Course learning module & Assessments \\
\hline LM 0. Introduction & $\begin{array}{ll}\text { - } & \text { Self-introduction forum (not graded) } \\
\text { - } & \text { Sample quiz (not graded) } \\
\text { - } & \text { Theoretical quiz } \\
\text { - } & \text { Question/answer forum } \\
\end{array}$ \\
\hline $\begin{array}{l}\text { LM 1. From preliminary design to } \\
\text { detailed design }\end{array}$ & $\begin{array}{ll}\text { - Homework (data flow from preliminary design to detailed } \\
\text { design) } \\
\text { - } \quad \text { Theoretical quiz } \\
\text { - } \quad \text { Question/answer forum }\end{array}$ \\
\hline LM 2. Intelligent planning & $\begin{array}{ll}\text { - } & \text { Homework (creating intelligent information) } \\
\text { - } & \text { Theoretical quiz } \\
\text { - } & \text { Question/answer forum }\end{array}$ \\
\hline $\begin{array}{l}\text { LM 3. Virtual design and } \\
\text { construction }\end{array}$ & $\begin{array}{ll}\text { - } & \text { Homework (4D simulation) } \\
\text { - } & \text { Theoretical quiz } \\
\text { - } & \text { Question/answer forum }\end{array}$ \\
\hline $\begin{array}{l}\text { LM 4. Visualization and virtual } \\
\text { reality (VR) }\end{array}$ & $\begin{array}{ll}\text { - } & \text { Homework (visualization }+ \text { interactive game) } \\
\text { - } & \text { Theoretical quiz } \\
\text { - } & \text { Question/answer forum }\end{array}$ \\
\hline $\begin{array}{l}\text { LM 5. Model based collaboration } \\
\text { (updated in } 2018 \text { autumn) }\end{array}$ & $\begin{array}{l}\text { Question/answer forum (shared project model through a web } \\
\text { service; commenting and answering to questions) }\end{array}$ \\
\hline $\begin{array}{l}\text { LM 6. Road rehabilitation (added } \\
\text { in } 2018 \text { autumn) }\end{array}$ & $\begin{array}{ll}\text { - } & \text { Homework (point cloud to road rehabilitation project) } \\
\text { - } & \text { Theoretical quiz } \\
\text { - } & \text { Question/answer forum } \\
\end{array}$ \\
\hline LM 7. Project & $\begin{array}{ll}- & \text { Essay } \\
\text { - } & \text { Presentation of the project (based on previous modules) }\end{array}$ \\
\hline
\end{tabular}

As such, it may happen that, if only one student is active at the start of the course, she/he should wait at least until one other student has reached the same learning point. Due to the flexible time management this is usually the case at the first learning module and it disappears once more students are involved. This issue can be resolved by setting 
deadlines and the teacher can always step in and keep the discussion going if there are too few students active. These questions and answers are assessed based on their constructiveness.

\section{Methods}

\section{Data collection}

The data used for analysis were obtained from two sources: (a) the university's study information system (number of declarations, final grades) and (b) students' individual activities with the completion date from an elearning environment. In addition, a feedback system at the end of the course was in place and responses were gathered. However, these course feedback responses cannot be fully used in the current research as key information, for example, whether student respondents "passed" or "failed" cannot be distinguished and, with the high drop-out rate, this may introduce bias into the analysis.

\section{Data measures}

The course in both years was taken by different study groups and it was intended to determine if student performance differs by study group. Division was made into 2 separate groups: (a) study program students; and (b) distance learning students. Although there could be many other variables affecting the drop-out rate (for example, previous knowledge) these are not taken into account in this preliminary analysis. In fact, the course did not have any compulsory prerequisites. The course in both years has been a compulsory subject for all student groups.

\section{Data analysis}

The preliminary analysis was carried out at two different levels of detail. Firstly, the key performance indicators of students' accomplishments were compared during the BIM course editions of 2017 spring and 2018 spring. Secondly, as more data was gathered during 2018, these were analyzed against learning outcomes where suggested learning module completion times should be followed but are not made compulsory except for the final deadline at the end of semester. These data give insights into students' capability to manage their time.

\section{Results}

\section{Core performance analysis (2017 vs 2018)}

The BIM course layout has evolved in time (Table 1). Table 3 summarizes the core statistics of the BIM courses that were delivered during 2017-2018. Table 3 shows that study program students have improved their completion rate, but the opposite is true of the distance learners. Distance learners can be further divided into three dynamic sub-groups (based on their activity): (a) those who register to the course; (b) those who start the course; and (c) those who complete the course. We can see that the average drop-out in between those sub-groups is $25-33 \%$. We explain this by the fact that the course needs more engagement and work during the semester and, if students fail to do it on their own, their motivation reduces.

Another possible reason that may explain the high dropout rate is that, according to the policy of the university, a student who starts the course in one semester can declare it again if it has not been successfully passed. Since dropping out does not have any serious repercussions for the future, the high-density course can easily be postponed in the hope of having more time or motivation in the future. In this study we have not yet been able to investigate such cases where the student retakes the course at a later time. The first such successful case was recorded in the 2018 autumn course but, due to limited time, that timeframe is not yet analyzed in the current research. It should be also noted that various universities do have different policies in terms of retaking the course and these may affect students' conduct. For example, in Tallinn University of Technology, retaking any course may have financial implications and this may compel more students to finish the course on their first attempt.

Table 3: A summary of student basic activity during the course

\begin{tabular}{|l|c|c|c|c|}
\hline \multirow{2}{*}{ Number of registrants (\% from total) } & \multicolumn{2}{|c|}{2017 spring } & \multicolumn{2}{c|}{2018 spring } \\
\cline { 2 - 5 } & $\begin{array}{c}\text { Study } \\
\text { programme }\end{array}$ & $\begin{array}{c}\text { Distance } \\
\text { learning }\end{array}$ & $\begin{array}{c}\text { Study } \\
\text { program }\end{array}$ & $\begin{array}{c}\text { Distance } \\
\text { learning }\end{array}$ \\
\hline First assessment (quiz) finished & $19(50 \%)$ & $19(50 \%)$ & $15(45 \%)$ & $18(55 \%)$ \\
\hline First modelling task finished (preliminary design) & 18 & 14 & 15 & 12 \\
\hline Course completed (\% from study group total) & 18 & 10 & 14 & 8 \\
\hline Average grade (max 5) & $15(79 \%)$ & $8(42 \%)$ & $14(93 \%)$ & $6(33 \%)$ \\
\hline Number of various graded assessments & 3.47 & 4.75 & 3.29 & 4.83 \\
\hline
\end{tabular}

This will be investigated in future research once the course has commenced in TalTech.

\section{Motivation vs performance and time management (2018)}

We take a closer look at how the motivation differs between those who finish the course and those who don't. "Motivation" here is defined in terms of a student's continuous activity. The analyses are divided according to the two main groups defined above. Starting with the fulltime study program students, Table 4 presents students' performance in terms of activity completion on-time. Positive numbers indicate the number of days ahead of time that an activity was finished, and negative numbers refer to learning activities completed after the suggested completion times (in days). It should be noted that the 
course has only one strict deadline, at the end of semester. Therefore, each student was able to apply his own time management to finish the course on time. Only one student (Student ID 12) did not complete the course, and this dropout occurred before the first assignment. We can clearly see that being behind the suggested completion date doesn't affect the possibility of finishing on time (for example, Student ID 7 began late and lagged the recommended schedule by almost 80 days). The final assignment's (7.2) assessment was carried out in the classroom. It was carried out in groups (2 students in one group) and at several dates.

The second study group, distance learning, is shown in Table 5. The first difference when compared with the previous study group, is the fact that only $33 \%$ of students reach the first assessment (which is also shown in Table 3 ). Either they do not start the course in Moodle at all or drop out in the introductory module (during assignments $0.1-0.4$ ). Also, one clear difference here is the average completion time of assignments. We see that distance learning students' complete assignments in a much shorter time. There are only two students who lag the schedule, they then try to start again but drop out around mid-course (learning module 3 ). With distance learning students we may connect the high drop-out with their daily duties because these students are participating in the course while also having (quite often) a full-time job.

\section{Conclusions}

During 2017-2018, a new BIM for Infrastructure course was developed for TTK UAS and TalTech as active learning courses. To reflect industry needs for students to develop a wide variety of skills, the course was created as a high-density course. This research focused on students' individual time management and how it relates to the course drop-out rate. It can be concluded that lagging behind the suggested learning schedule is not necessarily a problem and is not a major factor for explaining dropouts. Peer instruction was used throughout the course and could be a possible explanation for students finishing the course on-time, even if they lagged during the semester. Although the drop-out rate is much higher in the distance learning group, those who finish have demonstrated good time management throughout the course (lagging behind by an average of only 10 days). Overall, their performance has also improved over two semesters (in terms of higher grades). When it comes to study program students, their performance has dropped but the proportion completing the course has increased

Table 4: Time management of a study group "study program"

\begin{tabular}{|c|c|c|c|c|c|c|c|c|c|c|c|c|c|c|c|c|c|c|c|c|c|c|}
\hline \multirow{2}{*}{$\begin{array}{c}\text { Student } \\
\text { ID }\end{array}$} & \multicolumn{22}{|c|}{ Learning module } \\
\hline & 0.1 & 0.2 & 0.3 & 0.4 & 1.1 & 1.2 & 1.3 & 2.1 & 2.2 & 2.3 & 3.1 & 3.2 & 3.3 & 4.1 & 4.2 & 4.3 & 5.1 & 6.1 & 6.2 & 6.3 & 7.1 & 7.2 \\
\hline 1 & -1 & -18 & -4 & -10 & -1 & -9 & -10 & -1 & -3 & -3 & -29 & -31 & -31 & -25 & -29 & -31 & & & & & -29 & -12 \\
\hline 2 & -2 & -17 & -3 & -8 & 3 & -1 & -9 & 5 & 4 & -4 & 0 & -1 & -1 & -1 & -8 & -8 & & & & & -8 & 1 \\
\hline 3 & -3 & -17 & -3 & -9 & -8 & -8 & -8 & -17 & -18 & -23 & -21 & -22 & -25 & -30 & -31 & -31 & & & & & -39 & -8 \\
\hline 4 & -18 & -18 & -6 & -9 & -4 & -4 & -4 & 3 & 0 & -7 & -5 & -13 & -13 & -16 & -17 & -17 & \multirow{8}{*}{\multicolumn{4}{|c|}{$\begin{array}{l}\text { These modules } \\
\text { have been } \\
\text { added to the } \\
2019 \text { course } \\
\text { but were not } \\
\text { present in the } \\
\text { courses of } \\
2017-2018 \text {. }\end{array}$}} & -32 & -4 \\
\hline 5 & 3 & -18 & -5 & -10 & -39 & -41 & -41 & -45 & -48 & -48 & -50 & -50 & -50 & -44 & -44 & -44 & & & & & -40 & -11 \\
\hline 6 & 3 & -1 & -7 & -14 & -8 & -8 & -8 & 6 & 5 & 5 & 2 & 0 & -1 & 4 & 3 & -9 & & & & & -28 & 0 \\
\hline 7 & -18 & -18 & -15 & -79 & -66 & -67 & -67 & -58 & -59 & -59 & -52 & -53 & -53 & -46 & -49 & -49 & & & & & -39 & -12 \\
\hline 12 & -18 & -18 & -23 & & & & & & & & & & & & & & & & & & & \\
\hline 15 & -1 & -1 & -1 & -29 & 0 & -1 & -1 & -1 & -2 & -2 & 3 & 2 & -8 & -3 & -5 & -5 & & & & & 10 & 10 \\
\hline 16 & -3 & -18 & -4 & -14 & 0 & -10 & -37 & -43 & -44 & -44 & -37 & -37 & -37 & -30 & -54 & -54 & & & & & -40 & -12 \\
\hline 18 & -3 & -4 & -2 & -16 & -8 & -10 & -24 & -15 & -15 & -31 & -24 & -25 & -29 & -22 & -26 & -31 & & & & & -38 & -9 \\
\hline 20 & -18 & -18 & -7 & -21 & -18 & -18 & -18 & -11 & -15 & -15 & -11 & -12 & -27 & -22 & -24 & -24 & & & & & -39 & -9 \\
\hline 24 & -3 & -17 & -3 & -16 & -10 & -10 & -11 & -10 & -11 & -15 & -16 & -20 & -20 & -22 & -22 & -31 & & & & & -39 & -8 \\
\hline 28 & -21 & -21 & -7 & -8 & 1 & -2 & -2 & 4 & -2 & -18 & -11 & -23 & -23 & -16 & -17 & -17 & & & & & -17 & 5 \\
\hline 29 & -1 & -18 & -4 & -32 & -30 & -52 & -52 & -44 & -44 & -44 & -37 & -38 & -38 & -31 & -37 & -38 & & & & & -40 & -12 \\
\hline Average & -7 & -15 & -6 & -20 & -13 & -17 & -21 & -16 & -18 & -22 & -21 & -23 & -25 & -22 & -26 & -28 & & & & & -30 & -6 \\
\hline
\end{tabular}

Table 5: Time management of a distance learning study group 


\begin{tabular}{|c|c|c|c|c|c|c|c|c|c|c|c|c|c|c|c|c|c|c|c|c|c|c|}
\hline \multirow{2}{*}{$\begin{array}{c}\text { Student } \\
\text { ID }\end{array}$} & \multicolumn{22}{|c|}{ Learning module } \\
\hline & 0.1 & 0.2 & 0.3 & 0.4 & 1.1 & 1.2 & 1.3 & 2.1 & 2.2 & 2.3 & 3.1 & 3.2 & 3.3 & 4.1 & 4.2 & 4.3 & 5.1 & 6.1 & 6.2 & 6.3 & 7.1 & 7.2 \\
\hline 8 & -23 & -23 & -9 & -14 & & & & & & & & & & & & & & & & & & \\
\hline 9 & -7 & -7 & 0 & -1 & -4 & -7 & -7 & 0 & -1 & -1 & 6 & 5 & -1 & 1 & -1 & -1 & & & & & -4 & 5 \\
\hline 10 & -13 & hs & & & & & & & & & & & & & & & & & & & & \\
\hline 11 & -15 & -15 & -1 & -1 & 6 & 5 & 5 & 10 & 10 & 9 & 0 & -1 & -4 & 0 & -1 & -1 & \multirow{8}{*}{\multicolumn{4}{|c|}{$\begin{array}{l}\text { These modules } \\
\text { have been } \\
\text { added to the } \\
2019 \text { course } \\
\text { but were not } \\
\text { present in the } \\
\text { courses of } \\
\text { 2017-2018. }\end{array}$}} & -11 & 5 \\
\hline 13 & -5 & -5 & -7 & -14 & & & & & & & & & & & & & & & & & & \\
\hline 14 & -29 & -30 & -16 & -17 & -3 & -4 & -4 & 7 & 6 & 6 & -5 & -8 & -8 & -3 & -4 & -4 & & & & & -27 & -12 \\
\hline 17 & -8 & -8 & -2 & -14 & -9 & -10 & -64 & -50 & -51 & -55 & & & & & & & & & & & & \\
\hline 19 & -14 & -92 & -78 & & & & & & & & & & & & & & & & & & & \\
\hline 21 & -14 & -14 & -13 & -14 & -21 & -28 & -30 & -35 & -39 & -40 & -35 & & & & & & & & & & & \\
\hline 22 & -8 & & & & & & & & & & & & & & & & & & & & & \\
\hline 23 & -4 & -65 & -59 & -59 & & & & & & & & & & & & & & & & & & \\
\hline 25 & -3 & -7 & 1 & 1 & 4 & 4 & 4 & 7 & 7 & 7 & 0 & -7 & -7 & -4 & -4 & -4 & & & & & -7 & 5 \\
\hline 26 & -24 & -24 & -10 & -10 & 0 & 0 & -7 & 7 & 6 & 6 & 4 & 2 & -6 & -6 & -10 & -10 & & & & & -28 & -12 \\
\hline 27 & -7 & -7 & 1 & -12 & -4 & -15 & -15 & -14 & -16 & -16 & -9 & -11 & -11 & -8 & -10 & -10 & & & & & -27 & 3 \\
\hline Average & -12 & -23 & -15 & -13 & -3 & -6 & -13 & -7 & -8 & -9 & -4 & -2 & -5 & -2 & -4 & -4 & & & & & -14 & 0 \\
\hline
\end{tabular}

(from $79 \%$ in 2017 to $93 \%$ in 2018 ).

This may be partly explained in terms of the motivation associated with a study group because study program students see each other every week (through different courses) but distance learners see each other only once per month and their personal motivation is a key driver for them. To minimize the latter effect, both study groups were combined in Moodle into one big group, so that they were able to discuss each other's questions.

Future research and data analytics will focus more on the effectiveness of peer instruction, including: (a) how the number of a student's attempts to successfully complete an individual assessment change during the course as the amount of peer instruction increases (continuous support); (b) how the understanding of key terms develops through the course by carrying out text analytics of students' questions/answers given throughout the course. It is also crucial to compare the same methodology with other courses, that are built up in the same manner, in different universities and study groups.

\section{Acknowledgement}

This work was supported by the Estonian Research Council grant PUTJD742 and by the "Integrating Education with Consumer Behaviour Relevant to Energy efficiency and Climate Change at the Universities of Russia, Sri Lanka and Bangladesh (BECK) project cofunded by the Erasmus+ Programme of the European Union. The European Commission support for the production of this publication does not constitute an endorsement of the contents which reflects the views only of the authors, and the Commission cannot be held responsible for any use which may be made of the information contained therein.

\section{References}

Abbas, A., Din, Z.U. and Farooqui, R. (2016) Integration of BIM in construction management education: an overview of Pakistani Engineering universities.
Procedia Engineering, 145, pp. 151-157.

Abdirad, H. and Dossick, C.S. (2016) BIM curriculum design in architecture, engineering, and construction education: a systematic review. Journal of Information Technology in Construction, 21, pp. 250-271.

Alcalde, P. and Nagel, J. (2018) Why does peer instruction improve student satisfaction more than student performance? A randomized experiment. International Review of Economics Education, In Press, https://doi.org/10.1016/j.iree.2018.10.001.

Ally, M. (2004). Foundations of educational theory for online learning, in Anderson, T. and Elluomi, F. (eds): Theory and practice of online learning, pp. 3-31, Athabasca University

Anderson, T. (2011) The theory and practice of online learning (2nd Edition). Edmonton, AB: AU Press.

Bates, S. and Galloway, R. (2012) The inverted classroom in a large enrolment introductory physics course: a case study. Paper presented at HEA STEM Conference, London, United Kingdom.

Costin, A., Adibfar, A., Hu, H. and Chen, S.S. (2018) Building Information Modeling (BIM) for transportation infrastructure - Literature review, applications, challenges, and recommendation. Automation in Construction, 94, pp. 257-281.

Crouch, C.H. and Mazur, E. (2001) Peer instruction: Ten years of experience and results. American Journal of Physics, 69, pp. 970-977.

da Silva Vieira, M.M. and Neto, B.G.A. (2016) Peer instruction: continuing teacher education in higher education. Procedia - Social and Behavioral Sciences, 
217, pp. 249-256.

Fonseca, D., Redondo, E., Valls, F. and Villagrasa, S. (2017) Technological adaptation of the student to the educational density of the course. A case study: 3D architectural visualization. Computers in Human Behavior, 72, pp. 599-611.

Forsythe, P., Jupp, J. and Sawhney, A. (2013) Building information modelling in tertiary construction project management education - a programme-wide implementation strategy. Journal for Education in the Built Environment, 8(1), pp.16-34.

Freeman, S., Eddy, S.L., McDonough, M., Smith, M.K., Okoroafor, N., Jordt, H. and Wenderoth M.P. (2014) Active learning increases student performance in science, engineering, and mathematics. PNAS, June 10, 111(23), pp. 8410-8415.

Gustafsson, M., Gluch, P., Gunnemark, S., Heinke, K. and Engström, D. (2015) The role of VDC professionals in the construction industry. Procedia Economics and Finance, 21, pp. 478-485.

Halttula, H., Haapasalo, H. and Herva, M. (2015) Barriers to achieving the benefits of BIM. International Journal of 3-D Information Modeling (IJ3DIM), 4(4), pp. 1633.

Hsieh, S.-H., Amarnath, C.B. and Tsai, Y.-H. (2015) On teaching BIM technology courses in civil engineering. In International Conference on Innovative Production and Construction (IPC 2015), Perth, Western Australia, Australia, pp. 27-30.

Lassen, A. K., Hjelseth, E. and Tollnes, T. (2018) Enhancing learning outcomes by introducing BIM in civil engineering studies - experiences from a university college in Norway. International Journal of Sustainable Development and Planning, 13(1), pp. 6272.

Lindblad, H. and Vass S. (2015) BIM implementation and organizational change: a case study of a large Swedish public client. Procedia Economics and Finance, 21, pp.178-184.

Mazur, E. (1997) Peer instruction: Getting students to think in class. AIP Conference Proceedings, 399, pp. 981-988.

McKinsey\&Company (2017) Reinventing construction: a route to higher productivity. Available at: https:/www.mckinsey.com/industries/capitalprojects-and-infrastructure/our-insights/reinventingconstruction-through-a-productivity-revolution (accessed 26 September 2018).

Michinov, N., Morice, J. and Ferrières, V. (2015) A step further in Peer Instruction: Using the Stepladder technique to improve learning. Computers \& Education, 91, pp. 1-13.

Olawumi, T.O., Chan, D.W.M., Wong, J.K.W. and Chan, A.P.C. (2018) Barriers to the integration of BIM and sustainability practices in construction projects: A Delphi survey of international experts. Journal of Building Engineering, 20, pp.60-71.

Peterson, F., Hartmann, T., Fruchter, R. and Fischer, M. (2011) Teaching construction project management with BIM support: Experience and lessons learned. Automation in Construction, 20, pp. 115-125.

Rogelberg, S.G., Barnes-Farrell, J.L. and Lowe, C.A. (1992) The Stepladder technique: an alternative group structure facilitating effective group decision making. Journal of Applied Psychology, 77, pp. 730-737.

Russell, D., Cho, Y. K. and Cylwik, E. (2014) Learning opportunities and career implications of experience with BIM/VDC. Practice Periodical on Structural Design and Construction, 19(1), pp. 111-121.

Sacks, R. and Barak, R. (2010) Teaching building information modeling as an integral part of freshman year civil engineering education. Journal of Professional Issues in Engineering Education and Practice, 136(1), pp. 30-38.

Sacks, R. and Pikas, E. (2013) Building Information Modeling Education for Construction Engineering and Management. I: Industry Requirements, State of the Art, and Gap Analysis. Journal of Construction Engineering and Management, 139(11), pp. 04013016-12.

Sacks, R., Eastman, C., Lee, G. and Teicholz, P. (2018) BIM handbook: a guide to building information modeling for owners, designers, engineers, contractors, and facility managers. Wiley, Hoboken, New Jersey.

Won, J., Lee, G., Dossick, C. S. and Messner, J. (2013) Where to Focus for Successful Adoption of Building Information Modeling within Organization. Journal of Construction Engineering and Management, 139(1).

Succar, B., Sher, W. and Williams, A. (2013) An integrated approach to BIM competency assessment, acquisition and application. Automation in Construction, 35, pp. 174-189.

Tuchkevich, E., Rechinsky, A., Vysotskiy, A., Zolotova, J. and Tuchkevich, V. (2015) ADN and AP programs for civil engineering students. Procedia Engineering, 117 , pp. 1137-1142.

Uddin, M.M. and Khanzode, A.R. (2014) Examples of 
how building information modeling can enhance career paths in construction. Practice Periodical on Structural Design and Construction, 19(1), pp. 95-102.

Uhm, M., Lee, G. and Jeon, B. (2017) An analysis of BIM jobs and competencies based on the use of terms in the industry. Automation in Construction, 81, pp. 67-98.

Vinšová, I., Achten, H. and Matějovská, D. (2015) Integrating BIM in education: lessons learned. In proceedings of 33th annual conference of eCAADe, Vienna, Austria, pp. 127-133.

Wang, J., Jou, M., Lv, Y. and Huang, C.-C. (2018) An investigation on teaching performances of modelbased flipping classroom for physics supported by modern teaching technologies. Computers in Human Behavior, 84, pp. 36-48.

$\mathrm{Wu}, \mathrm{W}$. and Issa, R.R.A. (2013) BIM Education and Recruiting: Survey-Based Comparative Analysis of Issues, Perceptions, and Collaboration Opportunities. Journal of Professional Issues in Engineering Education \& Practice, 140(2), pp. 04013014-9.

Zingaro, D. and Porter, L. (2014) Peer Instruction in computing: The value of instructor intervention. Computers \& Education, 71, pp. 87-96. 